\title{
Manajemen Kepala Sekolah dalam Meningkatkan Profesionalisme Guru Akidah Akhlak di MI Muhammadiyah
} Kartasura

\author{
Muhammad Irfan \\ UIN Raden Mas Said Surakarta, Indonesia \\ Email: ervan.putraminang@gmail.com \\ Yusuf Rohmadi \\ UIN Raden Mas Said Surakarta, Indonesia \\ Email: yusufrohmadi.iainsurakarta@gmail.com
}

DOI: https://doi.org/10.21154/sajiem.v2i2.59

\begin{abstract}
This research was conducted to determine the principal's management in improving the professionalism of the akidah akhlak teachers at MI Muhammadiyah Kartasura and the inhibiting and supporting factors. This research approach uses a qualitative descriptive. The results of the study can be described as follows: 1. A teacher in order to increase his professionalism in carrying out his duties as a teacher, he must understand, master, and be skilled in using new learning resources. The role or efforts taken by the school principal in improving the professional competence of akidah akhlak teachers include the role of educator, manager, administrator, supervisor, and motivator. 2. The results of the inhibiting and supporting factors are: The inhibiting factor is the infrastructure and students while the supporting factor is the teachers who have a good educational background and there is good cooperation between teachers and fellow teachers, and teachers and principals.
\end{abstract}

Keywords: Management, principals, professionalism 


\section{Pendahuluan}

Upaya dalam membangun masyarakat modern di Indonesia, pendidikan memiliki peran yang sangat strategis dan fungsional. Pendidikan sebagai sarana yang didesain guna menciptakan suatu generasi baru bagi pemudapemudi yang tidak akan kehilangan ikatan dengan tradisi mereka sendiri tetapi sekaligus agar mereka tidak bodoh secara intelektual atau terbelakang.

Pendidikan merupakan upaya untuk mempersiapkan anak didik, agar mampu hidup dengan baik dalam bermasyarakat.Pendidikan diharapkan juga mampu mengembangkan peserta didik dan meningkatkan kualitas hidup mereka sendiri serta memberikan kontribusi positif yang mempunyai nilai dalam mengembangkan dan meningkatkan kualitas kehidupan dalam masyarakat banyak.

Upaya mewujudkan cita-cita pendidikan bangsa ini, maka sangat diperlukan seorang figur guru yang berkompetensi.Karena peranan guru yang sangat penting, maka guru sebagai jabatan profesional dalam hal ini tidak dapat dijabat oleh sembarang orang melainkan mereka yang telah dipersiapkan untuk jabatan dan tugas tersebut.

Dalam hal ini guru dituntut untuk memiliki seperangkat kemampuan dan teknik mengajar yang baik, dan juga dituntut untuk memiliki kepribadian yang utuh dalam rangka mengembangkan kepribadian peserta didik di samping menguasai ilmu ataupun bahan ajar, sebab guru merupakan tokoh teladan bagi diri siswa. Menurut Kunandar, "ditangan gurulah akan dihasilkan peserta didik yang berkualitas, baik secara akademis, skill (keahlian), kematangan emosional dan moral serta spiritual. Dengan demikian, maka akan menghasilkan generasi di masa depan yang siap hidup dengan tantangan zamannya. Karena itu, diperlukan sosok guru yang mempunyai kualifikasi, kompetensi, dan dedikasi yang tinggi dalam menjalankan tugas profesionalnya".

Hamzah B Uno mengatakan bahwa, "guru merupakan suatu profesi, yang berarti suatu jabatan yang memerlukan keahlian khusus sebagai guru dan tidak dapat dilakukan oleh sembarang orang di luar bidang pendidikan". ${ }^{2}$ Uzer Usman berpendapat bahwa "tugas guru sebagai suatu profesi meliputi mendidik, mengajar dan melatih. Mendidik berarti meneruskan dan mengembangkan nilai-nilai hidup.Mengajar berarti meneruskan dan mengembangkan ilmu pengetahuan dan teknologi, sedangkan melatih berarti mengembangkan ketrampilan-ketrampilan pada peserta didik" ${ }^{3}$

${ }^{1}$ Hamza B. Uno, Profesi Kependidikan problema, Solusi dan Reformasi Pendidikan di Indonesia. (Jakarta : Bumi Aksara, 2008), 40.

${ }^{2}$ Ibid,15.

${ }^{3}$ Usman, M. Uzer, Menjadi Guru Profesional. Bandung: Remaja Rosda Karya, 1999), 3. 
Seorang guru wajib memiliki kualifikasi akademik, kompetensi, sertifikat pendidik, sehat jasmani dan rohani, serta memiliki kemampuan untuk mewujudkan tujuan pendidikan nasional. Tertuang dalam undang - undang Republik Indonesia Nomor 14 Tahun 2005 tentang guru dan dosen "Kompetensi guru meliputi kompetensi pedagogik, kompetensi kepribadian, kompetensi sosial dan kompetensi profesional yang diperoleh melalui pendidikan profesi". ${ }^{4}$ Kemajuan ilmu pengetahuan dan teknologi di zaman globalisasi ini semakin canggih dan mengalami pertukaran yang sangat cepat.Maka profesionalisme guru dalam bidang tersebut sangat diharuskan.

Seorang guru harus peka dan tanggap terhadap perubahan-perubahan, pembaharuan serta ilmu pengetahuan dan teknologi yang terus berkembang sejalan dengan kebutuhan masyarakat dan perkembangan zaman.Uzer menambahkan "tugas guru untuk senantiasa meningkatkan wawasan ilmu pengetahuan, meningkatkan kualitas pendidikannya sehingga apa yang diberikan kepada peserta didiknya tidak terlalu ketinggalan dengan perkembangan kemajuan zaman".

Kenyataan sekarang ini masih banyak guru-guru yang belum profesional dalam menjalankan tugasnya. Banyak guru yang mengajarkan materi pelajaran yang tidak sesuai dengan rumpun bidang keilmuan yang dikuasainya, dengan alasan guna mengisi jam yang kosong dan alasan yang lainnya. Kebanyakan metode mengajar yang digunakan oleh guru pada saat mengajar hanya monoton saja tidak disesuaikan dengan materi pelajaran dan kondisi psikologis peserta didik.

Permasalah-masalah di atas yang banyak mengakibatkan seorang guru kurang profesional dalam menjalankan tugasnya adalah kurangnya sarana dan prasarana di sekolah tempat mereka mengajar serta berbagai macam persoalan hidup baik itu pribadi, keluarga maupun dalam masyarakat, serta hal-hal semacam itulah yang mengakibatkan seorang guru tidak profesional dalam mengajar.

Peran dan tugas seorang guru dari hari ke hari semakin berat, seiring dengan ilmu pengetahuan dan teknologi yang semakin berkembang.Seorang guru dalam dunia pendidikan sebagai komponen utama yang dituntut untuk mampu mengimbangi bahkan melampaui perkembangan ilmu pengetahuan dan teknologi yang berkembang dalam masyarakat.Melalui upaya guru di sekolah, diharapkan mampu menghasilkan peserta didik yang memiliki kompetensi tinggi dan siap menghadapi tantangan kehidupan dengan penuh keyakinan dan percaya diri yang tinggi.Sekolah (pendidikan) juga harus mampu menciptakan sumber daya manusia yang berkualitas, baik secara keilmuan (akademisi) maupun secara sikap dan mental.

${ }^{4}$ Undang-Undang Nomor 14 Tahun 2005. Tentang Keguruan,Undang-Undang Guru dan Dosen, 8-9. 
Beberapa tantangan globalisasi yang harus disikapi guru dengan mengedepankan profesionalisme menurut Kunandar diantaranya yaitu: "perkembangan ilmu pengetahuan dan teknologi yang begitu cepat dan mendasar. Dengan kondisi ini guru harus bisa menyesuaikan diri dengan responsif, arif dan bijaksana.Responsif artinya guru harus bisa menguasai dengan baik produk iptek, teutama yang berkaitan dengan dunia pendidikan, seperti pembelajaran dengan menggunakan multimedia.Tanpa penguasaan iptek yang baik, maka guru akan tertinggal dan menjadi korban iptek". ${ }^{5}$

Salah satu diantara beberapa paradigma baru yang harus diperhatikan guru dewasa ini menurut Kunandar adalah "guru mengikuti perkembangan ilmu pengetahuan dan teknologi yang mutakhir sehingga memiliki wawasan yang luas dan tidak tertinggal dengan informasi terkini. Guru mempunyai visi ke depan dan mampu membaca tantangan zaman sehingga siap menghadapi perubahan dunia yang tak menentu yang membutuhkan kecakapan dan kesiapan yang baik". 6

Dalam hal ini seorang guru pendidikan agama Islam sebagai tenaga pendidik yang terjun langsung dalam proses belajar mengajar juga harus bisa menguasai teknologi pendidikan. Sehubungan dengan hal tersebut peningkatan kompetensi profesional guru sangat diperlukan.Peningkatan kompetensi profesional guru tidak lepas dari peranan seorang kepala sekolah.

Wahjosumidjo mengatakan bahwa "keberhasilan suatu lembaga pendidikan sangat tergantung pada kepemimpinan kepala sekolah, keberhasilan sekolah adalah keberhasilan kepala sekolah". ${ }^{7}$ Bagaimanapun, kepala sekolah merupakan unsur vital bagi efektifitas lembaga pendidikan.Jarang kita jumpai sekolah yang baik dengan kepala sekolahnya yang buruk atau sebaliknya sekolah yang buruk dengan kepala sekolah yang baik. Sulistyorini berpendapat "Seorang kepala sekolah yang baik akan bersikap dinamis untuk menyiapkan berbagai macam program pendidikan. Bahkan, tinggi rendahnya mutu suatu sekolah akan dibedakan oleh kepemimpinan kepala sekolah".

Kepemimpinan juga berkaitan dengan permasalahan kepala sekolah dalam meningkatkan kesempatan untuk mengadakan pertemuan secara efektif dengan para guru dalam situasi yang kondisif.Perilaku seorang kepala sekolah harus dapat mendorong kinerja para guru dengan menunjukan rasa bersahabat, dekat dan penuh pertimbangan terhadap para guru, baik sebagai individu maupun sebagi kelompok.Sulistyorini menambahkan bahwa

${ }^{5}$ Kunandar, Guru Profesional Implementasi Kurikulum Tingkat Satuan Pendidikan (KTSP)dan Sukses dalam Sertifikasi Guru. (Jakarta: PT. Raja Grafindo Persada, 2008), 37.

ibid, 43.

${ }^{7}$ Wahjosumidjo, Kepemimpinan Kepala Sekolah Tinjauan Teoritik dan Permasalahannya. (Jakarta: Raja Grafindo Persada, 2005), 82.

${ }^{8}$ Sulistyorini, Manajemen Pendidikan Islam, (Yogyakarta: Teras, 20o9), 167. 
"perilaku pemimpin yang positif dapat mendorong kelompok dalam mengarahkan dan memotifasi individu untuk bekerja sama dalam kelompok dalam rangka mewujudkan tujuan lembaga pendidikan"9.

Figur kepala sekolah merupakan pemimpin pendidikan yang mempunyai peranan penting dalam mengembangkan kualitas pendidikan.Seorang kepala sekolah sebagai administrator harus mampu mendayagunakan sumber yang tersedia secara optimal. Begitupun sebagai manajer, kepala sekolah harus mampu bekerjasama dengan orang lain dalam organisasi sekolah. Sebagai pemimpin pendidikan, seorang kepala sekolah juga harus mampu mengkoordinasi dan menggerakkan potensi manusia untuk mewujudkan tujuan pendidikan.Juga sebagai supervisor, kepala sekolah harus mampu membantu guru meningkatkan kapasitasnya untuk membelajarkan peserta didik secara optimal. Dengan begitu maka, seorang kepala sekolah diharapkan dengan sendirinya dapat mengelola lembaga pendidikan yang dipimpinnya kearah perkembangan yang lebih baik dan dapat menjanjikan untuk masa depan.

Kepala sekolah sebagai pemimpin di Madrasah Ibtidaiyah (selanjutnya disingkat MI) Muhammadiyah Kartasura, yang bertanggung jawab terhadap berlangsungnya proses pembelajaran di sekolah tersebut. Sehingga kepala sekolah dituntut untuk bisa memberikan pembinaan, bimbingan, motivasi, pengawasan dan evaluasi dalam proses pembelajaran dalam upaya guna mencapai kualitas pembelajaran yang baik. Sementara, dari hasil wawancara dengan salah satu guru Akidah Akhlak di MI Muhammadiyah Kartasura bahwa kepala sekolah menyerahkan sepenuhnya kepada guru mata pelajaran yang berkaitan dengan perangkat pengajaran, kegiatan pembelajaran, sampai pada evaluasi pembelajaran. Sehingga guru harus berusaha dengan sendirinya mewujudkan proses pembelajaran yang kondusif dan dapat berjalan sebagaimana mestinya. ${ }^{10}$

Berdasarkan hasil studi awal di atas, dapat diketahui bahwa kepala sekolah dalam melaksanakan tugasnya sebagai supervisor, belum terlaksana dengan efektif.Karena kepala sekolah masih menyerahkan sepenuhnya kepada guru, tanpa memberikan bimbingan dan arahan dalam hubungannya dengan perencanaan, pelaksanaan dan evaluasi pembelajaran. Sementara kepala sekolah sebagai supervisor dituntut memberikan pembinaan, bimbingan, motivasi, pengawasan dan evaluasi dalam proses pembelajaran guna mencapai pembelajaran yang berkualitas.

Sementara di sisi yang lain, hasil pengamatan sementara di MI Muhammadiyah Kartasura, ditemukan bahwa guru dalam menyampaikan mata pelajaran Akidah Akhlak masih terdapat kekurangan, yakni ketika

\footnotetext{
${ }^{9}$ ibid,168.

${ }^{10}$ Wawancara dengan Ibu Ummi, guru Akidah Akhlak, MI Muhammadiyah Kartasura, pada tanggal 21 September 2020.
} 
proses pembelajaran kondisi kelas dan siswa belum terkondisikan. Sebagai contoh, siswa masih banyak yang tidak memperhatikan guru ketika menjelaskan, masih adanya siswa keluar masuk ketika proses pembelajaran berlangsung, sementara guru kurang menghiraukan kondisi tersebut."

Berdasarkan hasil studi awal di atas, maka perlu dilakukan penelitian dengan judul "Manajemen Kepala Sekolah Dalam Meningkatkan Profesionalisme Guru Akidah Akhlak di MI Muhammadiyah Kartasura". Dalam hal ini bagaimana sebenarnya strategi yang dilakukan kepala sekolah sebagai pemimpin dalam meningkatkan kompetensi profesional guru pada mata pelajaran Akidah Akhlak, sehingga Pendidikan Akidah Akhlak bisa berjalan dengan baik dan sesuai dengan tujuan yang ingin dicapai.

Berdasarkan latar belakang masalah maka dapat dirumuskan masalah yang diteliti : 1) Bagaimana manajemen kepala sekolah dalam meningkatkan profesionalisme guru akidah akhlak di MI Muhammadiyah Kartasura?, 2) Apa saja faktor penghambat kepala sekolah dalam upaya meningkatkan profesionalisme guru akidah akhlak di MI Muhammadiyah Kartasura?.

Penelitian ini bertujuan untuk: 1) Mendeskripsikan manajemen kepala sekolah dalam upaya meningkatkan profesionalisme guru pada proses pembelajaran akidah akhlak, 2) Mendeskripsikan faktor penghambat dan pendukung kepala sekolah dalam upaya meningkatkan profesionalisme guru akidah akhlak di MI Muhammadiyah Kartasura.

\section{Metode Penelitian}

Pendekatan penelitian ini menggunakan deskriftif kualitatif. ${ }^{12}$ Setting penelitian dilakukan di MI Muhammadiyah Kartasura, waktu penelitian bulan September 2020 sampai dengan bulan Maret 2021. Subyek penelitian yaitu Kepala sekolah. Informan penelitian wakil kepala sekolah, guru kelas, guru Akidah Akhlak. Metode pengumpulan data menggunakan observasi, wawancara dan dokumen. Pemeriksaan keabsahan data menggunakan triangulasi sumber. Teknik analisis data menggunakan metode diskriftif dengan teknik interaktif model. Teknik ini terdapat tiga alur yaitu reduksi data, penyajian data dan menarik kesimpulan. ${ }^{13}$

\section{Pembahasan}

\section{Manajemen Kepala Sekolah Dalam Meningkatkan Profesionalisme Guru Akidah Akhlak}

Manajemen kepala sekolah dalam meningkatkan profesionalisme guru akidah akhlak dilakukan dengan berbagai macam upaya. Peningkatan pada

\footnotetext{
${ }^{11}$ Observasi di MI Muhammadiyah Kartasura, pada tanggal 21 September 2020.

${ }^{12}$ Sugiyono,Memahami Penelitian Kualitatif, (Bandung: Alfabeta, 2009), 11.

${ }^{13}$ Djam'an Satori dan Aan Komariah, Metodologi Penelitian Kualitatif, (Bandung: Alfabeta, Cet. I, 2009), 221.
} 
aspek profesionalisme guru akidah akhlak ini dimaksukan untuk mengimbangi kemajuan zaman. Sedangkan tugas dan kewajiban bagi semua guru baik yang terkait langsung dengan proses belajar mengajar maupun yang tidak, sangatlah banyak dan memiliki pengaruh yang besar pada hasil belajar mengajar. Hal ini, perlu diperhatikan secara sungguh-sungguh bagaimana memberikan prioritas yang tinggi kepada guru, sehingga mereka dapat memperoleh kesempatan untuk selalu meningkatkan kemampuannya dalam melaksanakan tugasnya.

Guru harus diberikan kepercayaan dalam melaksanakan tugasnya agar proses belajar mengajar menjadi baik. Guna meningkatkan kompetensinya dalam melaksanakan tugas sebagaiseorang guru, dia harus memahami, menguasai dan terampil dalam menggunakan sumber-sumber belajar baru. apabila guru tidak mampu menyesuaikan diri dengan perkembangan dan perubahan zaman, maka guru tersebut akan mudah ditinggalkan oleh peserta didiknya. Seorang guru perlu diberikan dorongan dan motivasi untuk menemukan berbagai alternatif metode dan cara mengembangkan proses pembelajaran sesuai dengan perkembangan zaman. Maka sudah sepatutnya manajemen kepala sekolah sangat diperlukan dalam meningkatkan profesionalisme bagi semua guru, termasuk juga pada guru akidah akhlak. Upaya dan manajemen yang ditempuh kepala sekolah dalam meningkatkan kompetensi profesional guru akidah akhlak adalah sebagai berikut:

\section{a. Kepala Sekolah sebagai Edukator}

Sesuai dengan fungsinya sebagai educator, seorang kepala sekolah harus memiliki strategi yang tepat untuk meningkatkan profesionalisme tenaga kependidikan di sekolahnya. Hal tersebut dapat dilakukan dengan cara menciptakan iklim sekolah yang kondusif, memberikan nasehat kepada warga sekolah, memberikan dorongan kepada seluruh tenaga kependidikan, serta melaksanakan model pembelajaran yang menarik.

Sebagai seorang edukator, kepala sekolah juga harus selalu berupaya meningkatkan kualitas pembelajaran yang dilakukan oleh para guru. Hal ini dilakukan dengan cara membimbing para guru dalam menyusun program pengajaran, melaksanakan programpengajaran, mengevaluasi hasil belajar, menganalisis hasil evaluasi belajar, dan melaksanakan program pengayaan dan perbaikan. Dalam hal ini bapak Adi sebagai kepala sekolah di MI Muhammadiyah Kartasura, selalu berupaya untuk memberikan bimbingan kepada para guru, sebagaimana yang diutarakan oleh beliau, ${ }^{14}$ sebagai berikut:

"Salah satu upaya yang saya lakukan sebagai kepala sekolah untuk meningkatkan kualitas pembelajaran guru-guru disini adalah

\footnotetext{
${ }^{14}$ Wawancara pada tanggal 22 Januari 2021.
} 
dengan memberikan pembinaan kepada guru-guru tentang bagaimana dalam menyusun silabus dan lesson plan sesuai dengan prinsip-prinsipnya, saya membimbing guru-guru dalam menentukan metode pembelajaran yang sesuai dengan peserta didiknya, agar pembelajaran menjadi aktif dan inovatif. Selain itu, saya juga tidak lupa untuk selalu memotivasi para guru supaya dapat memanfaatkan alat ajar serta teknologi informasi agar pembelajaran semakin baik."

Pernyataan senada juga disampaikan oleh Ibu Ummi selaku guru akidah akhlak di MI Muhammadiyah Kartasura, beliau mengatakan:

"Biasanya setelah bapak kepala sekolah menyelesaikan supervisi diadakan evaluasi terhadap hasil supervisi tersebut. Kemudian dari evaluasi tersebut bapak kepala sekolah memberikan bimbingan terhadap kekurangan-kekurangan pada saat pelaksanaan pembelajaran. Bahakan, bapak kepala sekolah juga selalu memberi bimbingan terkait dengan perangkat pembelajaran, mulai dari Program tahunan, Program Semester, silabus, Lesson plan hingga evaluasi terhadap program-program." ${ }^{\prime \prime}$

Merujuk pada pernyataan diatas dapat disimpulkan bahwa peran kepala sekolah sebagai pendidik salah satunya adalah melakukan bimbingan terhadap guru. Dengan adanya bimbingan yang intensif kepada para guru ini kepala sekolah dapat mengetahui kekurangankekurangan maupun permasalahan yang dihadapi para guru sehingga dapat mencari solusi yang tepat untuk mengatasinya.

Selain bimbingan kepada para guru, bapak Kepala Sekolah juga tidak lupa memberikan bimbingan kepada para siswa. Beliau mengungkapkan bahwa:

"Selain tugas saya sebagai kepala sekolah, saya juga mengajar juga mengajar di bidang studi Pendidikan Agama Islam. Dengan mempunyai jam mengajar di kelas saya bisa berinteraksi lebih dekat dengan anak-anak sehingga saya bisa mengetahui dengan jelas mengenai perkembangan situasi dan kondisi tiap kelas di sekolah ini." ${ }^{16}$

\footnotetext{
${ }^{15}$ Wawancara pada tanggal 8 Februari 2021.

${ }^{16}$ Wawancar pada tanggal 22 Januari 2021.
} 
Merujuk pada pemaparan di atas dapat diketahui bahwa peran kepala sekolah sebagai educator atau pendidik tidak hanya dengan melakukan pembinaan terhadap para guru saja, melainkan juga kepada para peserta didik guna mengetahui sejauh mana perkembangan situasi dan kondisi tiap kelas serta perkembangan tiap peserta didiknya.

Selain memberikan bimbingan kepada para guru dan peserta didik, upaya yang dilakukan kepala sekolah sebagai educator, khususnya dalam peningkatan kinerja tenaga kependidikan adalah dengan mengikutsertakan guru-guru dalam kegiatan pelatihan-pelatihan. Kegiatan pelatihan ini dimaksudkan untuk mengembangkan kemampuan guru dibidang penguasaan materi pembelajaran, penggunaan metode ketika mengajar di kelas dan kelengkapan administrasi. Hal ini sebagaimana diutarakan oleh bapak Rochmadi, S.Pd.I yang akrab dipanggil bapak Adi selaku kepala sekolah, beliau mengungkapkan bahwa:

"Untuk meningkatkan kemampuan dan kompetensi guru-guru disini, saya selalu mengikutsertakan semua guru dalam pelatihanpelatihan maupun workshop guru. Karena dengan mengikuti pelatihan-pelatihan tersebut, guru-guru yang belum begitu menguasai administrasi dengan baik, seperti pembuatan Jurnal, Prota, Promes, Silabus, dan Leasson plan agar menjadi lebih pandai. Termasuk juga dalam hal metode pembelajaran supaya guru-guru lebih kreatif dan inovatif lagi dalam menyampaikan materi pada siswa-siswi ketika proses pembelajaran berlangsung." ${ }^{\prime 7}$

Hal tersebut dapat dibuktikan melalui dokumentasi pelatihan dan pembinaan terhadap guru-guru yang peneliti temukan pada perangkat akreditasi MI Muhammadiyah Kartasura. Pelatihan dan pembinaan tersebut dilakukan di lingkungan sekolah dan di luar sekolah.

Selanjutnya Ibu Ummi Sholikhah, S.Pd.I selaku guru akidah akhlak di MI Muhammadiyah Kartasura juga mengungkapkan bahwa :

"Untuk pelatihan sendiri, sering sekali saya diikutsertakan oleh bapak kepala sekolah untuk mengikuti pelatihan-pelatihan baik itu dalam bentuk workshop guru. Dengan begitu saya bisa paham tentang perkembangan metode-metode pembelajaran zaman

\footnotetext{
${ }^{17}$ Wawancara pada tanggal 22 Januari 2021.
} 
sekarang. Dari pembekalan tersebut maka dapat saya terapkan pada proses pembelajaran di kelas."

Senada juga dengan yang diungkapkan oleh wakil Kepala Sekolah Ibu Dewi Maya Ayu Septiana, S.Pd. beliau mengungkapkan bahwa :

"Banyak sekali usaha yang yang dilakukan oleh bapak kepala sekolah untuk meningkatkan profesionalisme guru-guru disini mas. Seperti mengikutsertakan guru-guru disini pada workshop atau pelatihan di dalam maupun luar lingkungan sekolah. Hal ini bertujuan untuk memberikan pembekalan bagi guru-guru disini terkait denganadministrasi dan rancangan-rancangan pembelajaran selama satu tahun ajaran." ${ }^{19}$

Selain kegiatan pelatihan dan workshop guru, kegiatan-kegiatan seperti kelompok kerja guru (KKG) juga membantu guru-guru dalam meningkatkan kemampuan dalam penggunaan metode ketika mengajar di kelas dan kelengkapan administrasi. Dalam hal ini Kepala Sekolah yakni bapak Adi menyatakan bahwa kegiatan-kegiatan tersebut memiliki manfaat yang besar bagi guru, termasuk juga bagi guru akidah akhlak. Sebagaimana bapak Adi juga mengungkapkan bahwa :

"Kegiatan-kegitan seperti KKG memang saya haruskan dan wajibkan bagi setiap guru disini mas, termasuk juga guru akidah akhlak. Baik KKG di tingkat sekolah, kecamatan maupun kota. Karena kegiatan seperti itu manfaatnya banyak sekali mas. Dengan mengikuti kegiatan tersebut guru-guru diharapkan dapat memperbaiki dan meningkatkan kemampuan para guru dalam menyusun administrasi dan perangkat pembelajaran yang selama ini menjadi kendala bagi guru-guru disini."

Hal yang sama juga diungkapkan oleh ibu Ummi selaku guru akidah akhlak bahwa :

"Kalau kegiatan seperti KKG saya rutin mengikutinya mas, karena disitu saya bisa berkumpul dan berdiskusi dengan guru-guru dari sekolah lain dan bisa saling tukar ilmu baru mas. Biasanya yang dibahas itu mulai tentang perangkat pembelajaran seperti Leasson plan atau RPP, silabus, dsb dan juga metode-metode

\footnotetext{
${ }^{18}$ Wawancara pada tanggal 8 Februari 2021.

${ }^{19}$ Wawancara pada tanggal 25 Januari 2021.

${ }^{20}$ Wawancara pada tanggal 22 Januari 2021.
} 
pembelajaran, sampai perkembangan materi pembelajaran saat ini. Jadi banyak sekali manfaat yang saya dapatkan mas." ${ }^{21}$

Merujuk pada beberapa pernyataan diatas dapat disimpulkan bahwa manajemen dan peran kepala sekolah sebagai educator atau pendidik adalah dengan memberikan bimbingan kepada para guru, memberikan bimbingan kepada peserta didik, mengikutsertakan para guru dalam kegiatan pelatihan-pelatihan, worksop guru dan KKG dsb. Kegiatankegiatan tersebut dilakukan dalam rangka upaya kepala sekolah untuk meningkatkan kompetensi dan Profesionalisme guru di bidang pembelajaran sehingga guru-guru dapat melaksanakan tugasnya sebagai pendidik secara optimal.

\section{b. Kepala Sekolah sebagai Manajer}

Salah satu tugas yang harus dilakukan kepala sekolah dalam mengelola tenaga kependidikan, adalah melaksanakan kegiatan pemeliharaan dan pengembangan profesi para guru. Hal ini, seyogyanya dapat memfasilitasi dan memberikan kesempatan yang luas kepada para guru untuk dapat melaksanakan kegiatan pengembangan profesi melalui berbagai kegiatan pendidikan dan pelatihan.

Kaitannya dengan peran kepala sekolah sebagai manajer bapak Adi sebagai kepala sekolah mengatakan bahwa :

"Guna mewujudkan tujuan sekolah, tentu saja ada programprogram yang sudah saya susun. Baik itu program jangka menengah sampai program jangka panjang. Misalnya program jangka pendek itu dibuat untuk satu tahun ajaran, kemudian jangka menengah untuk program-program selama dua sampai lima tahun, dan jangka panjang untuk lima sampai sepuluh tahun kedepan. Berbagai program ini tentu saja berkesinambungan antara satu dengan yang lainnya. Saya berharap program-program yang telah kami susun secara bertahap ini dapat berjalan lancar dan bisa mengembangkan sekolah ini menjadi lebih baik lagi."

Terkait dengan peran kepala sekolah sebagai manajer ini, wakil kepala sekolah Ibu Dewi juga menambahkan bahwa :

"Setiap menjelang awal tahun ajaran baru, bapak kepala sekolah selalu mengadakan musyawarah untuk membahas tentang perencanaan program-program yang akan kami jalankan selama satu semester kedepan, yang mana nantinya program-program

\footnotetext{
${ }^{21}$ Wawancarapada tanggal 8 Februari 2021.
} 
tersebutlah yang akan dimasukkan kedalam kalender pendidikan sekolah. Sehingga kita bisa mempersiapkan hal-hal apa saja yang dibutuhkan guna mensukseskan program-program yang telah direncanakan tersebut. Ketika musyawarah bapak kepala sekolah juga memberikan kesempatan kepada semua guru untuk memberikan ide maupun pendapat terkait dengan program yang akan kami jalankan selama satu semester kedepan."

Sejalan dengan kedua paparan di atas, Ibu Ummi sebagai Guru akidah akhlak juga memberikan tambahan sebagai berikut:

"Benar mas, setiap awal semester bapak kepala sekolah selalu mengadakan rapat untuk membahas tentang rencana programprogram maupun kegiatan-kegiatan yang akan kami jalankan selama satu semester kedepan. Beliau juga membagikan tugas kepada guru-guru supaya dapat mempersiapkan programprogramtersebut sesuai dengan bidangnya, misalnya saja saya sebagai guru akidah akhlak ditugaskan untuk melakukan persiapan terhadap program-program yang terkait dengan kegiatan Keagamaan."

Mengacu pada beberapa paparan wawancara di atas, maka dapat disimpulkan bahwa tugas kepala sekolah sebagai manajer diantaranya adalah dengan melakukan perencanaan terhadap penyusunan programprogram jangka pendek, jangka menengah, dan jangka panjang. Dengan adanya berbagai program tersebut akan dapat membantu kepala sekolah untuk mewujudkan visi dan misi sekolah.

\section{c. Kepala Sekolah sebagai Administrator}

Sebagai seorang administrator, kepala sekolah bertanggung jawab terhadap kelancaran pelaksanaan pendidikan dan pengajaran di sekolahnya. Ia harus selalu berusaha agar segala sesuatu disekolahnya berjalan lancar. Hal tersebut mencakup seluruh kegiatan sekolah, seperti proses belajar mengajar, kesiswaan, personalia, sarana prasarana, ketatausahaan dan keuangan serta mengatur hubungan sekolah dengan masyarakat.

Terkait dengan hal diatas, bapak Adi sebagai kepala sekolah ketika ditanya dalam wawancara beliau menuturkan sebagai berikut:

"Saya sebagai kepala sekolah disini, selalu membuat perencanaan sebelum memasuki awal semester maupun awal tahun ajaran baru. seperti mebuat rencana jangka pendek sampai rencana jangka panjang. Contohnya saja seperti menyusun kurikulum 
sekolah dengan para guru, kemudian menyusun struktur organisasi sekolah dan mendelegasikan tugas-tugas dan wewenang kepada setiap anggota administrasi sekolah. Contoh lainnya adalah ketika awal tahun ajaran baru kami mempersiapkan kegiatan penerimaan peserta didik baru seperti menentukan syarat-syarat penerimaannya dan pengelompokan siswan hingga pembagian kelas mereka. Selain itu saya juga tidak lupa untuk membagi tugas kepada para guru untuk mengisi kelaskelas yang telah ditentukan."

Pernyataan senada juga diungkapkan oleh Ibu Dewi selaku wakil kepala sekolah, beliau mengungkapkan bahwa :

"Sebagai wakil kepala sekolah, salah satu tugas saya disini adalah membantu bapak kepala sekolah dalam penyusunan organisasi sekolah. Seperti halnya dalam penyusunan kurikulum sekolah kemarin bapak kepala sekolah membentuk tim khusus dalam menyusun kurikulum yang sesuai dengan keahlian di bidang tersebut. Dan juga setiap sebelum mengadakan suatu kegiatan di sekolah, bapak kepala sekolah selalu melakukan rapat koordinasi dengan para guru untuk membagi tugas kepada masing-masing guru."

Maka dapat diambil kesimpulan dari beberapa pernyataan diatas bahwa peran kepala sekolah sebagai administrator diantaranya adalah kepala sekolah harus memiliki kemampuan dalam hal mengelola administrasi sekolah seperti menyusun kurikulum sekolah, struktur organisasi sekolah, hingga menyusun administrasi yang berkaitan dengan peserta didik.

\section{d. Kepala Sekolah sebagai Supervisor}

Termasuk dalam salah satu tugas kepala sekolah/madrasah adalah melaksanakan supervisi akademik. Supervisi dilakukan dengan tujuan untuk mengembangkan kemampuan dalam proses belajar mengajar bagi seorang guru. Supervisi ini dilakukan langsung oleh kepala sekolah dengan bantuan dari wali kelas. Sebagaimana dituturkan bapak Adi ketika peneliti wawancarai berikut :

"Benar mas, untuk supervisi kita lakukan setiap dua bulan sekali, yaitu untuk mengetahui sejauh mana pelaksanaan pembelajaran yang selama ini sudah berlangsung. Biasanya kami melakukan supervisi dengan mengevaluasi mulai dari memantau pelaksanaan kegiatan belajar mengajar di dalam kelas dan juga mengevaluasi 
kelengkapan perangkat pembelajaran para guru. Sehingga jika ada yang kurang sesuai bisa kita carikan solusinya."

Hal senada juga dituturkan oleh Ibu Ummi selaku guru akidah akhlak menyatakan bahwa :

"Pelaksanaan supervisi dari bapak kepala sekolah untuk semua guru. Biasanya bapak Adi memantau kami, para guru ketika melaksanakan pembelajaran di dalam kelas, apakah sudah sesuai ataubelum. Seandainya ada suatu permasalahan atau evaluasi dari bapakkepala sekolah biasanya disampaikan ketika rapat dengan paraguru."

Merujuk pada paparan diatas dapat diketahui bahwa tugas kepala sekolah sebagai supervisor diwujudkan dalam kemampuannya menyusun dan melaksanakan program supervisi pendidikan serta memanfaatkan hasilnya. Dengan adanya supervisi tersebut kepala sekolah dapat mengetahui sejauh mana pelaksanaan pembelajarandi dalam kelas yang kemudian diadakan evaluasi dan mencari solusi yang tepat untuk mengatasi permasalah yang ditemukan.

\section{e. Kepala Sekolah Sebagai Motivator}

Kepala sekolah sangat memegang peranan penting dalam mencapai tujuan sekolah. Memotivasi guru dan karyawan dapat mendorong efektifitas pencapaian tujuan sekolah, karena dengan motivasi tersebut guru dan karyawan akan senantiasa berusaha untuk selalu meningkatkan kemampuan serta kompetensinya baik prestasi maupun kinerjanya.

Berikut adalah pernyataan bapak Adi selaku kepala sekolah yang berkenaan dengan pemberian motivasi :

"Memberikan dorongan dan motivasi kepada guru-guru itu sangat penting mas, tujuannya agar dapat menambah semangat bagi para guru agar dapat meningkatkan kinerjanya. Biasanya kita lakukan sharing kecil-kecilan untuk mendengarkan apa saja keluhan dan kesulitannya selama proses pembelajaran di kelas. Kemudian dari situlah kita bisa berikan motivasi dan semangat bagi guru yang mengalami kesulitan tersebut."

Hal tersebut diperkuat dengan pernyataan guru akidah akhlak Ibu Ummi sebagai berikut :

"Bapak kepala sekolah sendiri sering memberikan motivasi untuk saya, terutama supaya saya bisa lebih meningkatkan kinerja dan kompetensi saya sebagai seorang guru akidah akhlak. Apalagi bapak kepala sekolah juga seorang guru, jadi beliau mengerti 
kendala yang saya hadapi sehingga beliau selalu memberikan dorongan untuk saya agar bisa memberikan yang terbaik bagi para siswa."

Dengan dorongan dan motivasi dari kepala sekolah akan mampu memberikan semangat yang lebih bagi para guru untuk meningkatkan kinerjanya. Pemberian reward terhadap guru yang berprestasi juga memiliki pengaruh terhadap peningkatan kinerja guru itu sendiri. Adanya sharing sesama guru dan saling memotivasi satu dengan yang lain juga mampu meningkatkan kenyamanan dan semangat untuk bekerja.

\section{Profesionalisme Guru Akidah Akhlak di MI Muhammadiyah Kartasura}

Pendidikan dapat dikatakan bermutu apabila mempunyai tenaga pendidik yang sesuai dengan standar mutu guru. Oleh karena itu, tenaga pendidik merupakan salah satu komponen penting dalam menunjang keberhasilan pendidikan. Zaman sekarang ini ilmu dan pengetahuan selalu berkembang maka profesionalisme guru pun perlu ditingkatkan termasuk didalamnya adalah profesionalisme guru akidah akhlak.

Di MI Muhammadiya Kartasura ini profesionalisme dari guru akidah akhlak disini terbilang cukup bagus. Hal ini peneliti buktikan melalui observasi pada saat proses kegiatan belajar mengajar, disini peneliti lihat bahwa guru akidah akhlak MI Muhammadiyah Kartasura, yakni Ibu Ummi ketika mengajar di kelas beliau selalu menyiapkan materi pembelajaran yang akan diajarkan. Termasuk menyiapkan perangkat pembelajaran dan metode yang akan dibawakan ketika mengajar. ${ }^{22}$

Seperti halnya yang diungkapkan oleh Ibu Ummi saat wawancara, beliau mengatakan bahwa :

"Sebelum mengajar biasanya saya sudah menyiapkan Leasson plan atau RPP yang akan saya gunakan untuk hari itu, lalu saya juga sempatkan untuk membaca tentang materi yang akan saya ajarkan pada anak-anak."

Pada saat observasi yang peneliti lakukan, terlihat Ibu Ummi sudah menyiapkan perangkat dan materi yang akan diberikan pada siswanya. Beliau terlihat sudah menyiapkan metode pembelajaran yang sesuai dengan kondisi dan karakteristik yang ada pada siswa-siswinya. Hal ini sangatlah penting bagi seorang guru untuk menerapkan metode pembelajaran agar materi yang disampaikannya bisa diterima dengan baik bagi siswa-siswi. Hal tersebut juga diungkapkan oleh Ibu Ummi, sebagai berikut :

${ }^{22}$ Observasi di MI Muhammadiyah Kartasura, pada tanggal 21 September 2020, ketika masih diperbolehkannya tatap muka secara bergantian semasa Covid-19. 
"Sebelum memulai pelajaran baiknya adalah materi sebaiknya disiapkan dengan baik, karena kalau tidak maka pelajarannya tidak dapat maksimal mas. Metode pembelajarannya sendiri juga sudah saya siapkan, tapi juga terkadang menyesuaikan kondisi di kelas mas."

Sebagai seorang guru Ibu Ummi juga selalu membekali dirinya dengan berbagai pelatihan dan pembinaan. Beliau selalu menyempatkan waktu untuk mengikuti Seminar, Workshop, dan pelatihan lainnya.Profesionalisme guru akidah akhlak di MI Muhammadiyah Kartasura ini terbilang sudah cukup bagus, namun tetap juga harus diupayakan peningkatan kualitas agar tujuan dari sekolah tersebut dapat terpenuhi dengan baik sesuai dengan sasaran yang diinginkan. Hal tersebut diungkapkan oleh Kepala Sekolah Bapak Adi bahwa : "untuk Profesionalisme guru-guru disini sudah cukup baik mas, akan tetapi juga perlu ditingkatkan lagi agar dapat menyesuaikan dengan tuntutan dan tantangan guru di zaman sekarang. Untuk guru akidah akhlak sendiri juga sudah cukup baik mas, sudah melaksanakan tugas pokoknya sebagai seorang guru dengan baik, hanya saja perlu dimaksimalkan lagi untuk menuju tahap yang lebih profesional lagi."

Hal Senada dengan apa yang juga diungkapkan oleh wakil kepala sekolah yaitu Ibu Dewi sebagai berikut:

"Kalau untuk guru akidah akhlak disini sudah cukup bagus mas, beliau ketika mengajar selalu berusaha untuk memahamkan anakanak, walaupun ada beberapa kendala untuk memahamkan anakanak tertentu, akan tetapi masih bisa ditangani. Untuk metode pembelajaran yang digunakan juga mudah dipahami oleh anakanak. Ibu Ummi juga sering kali melakukan praktik langsung supaya anak-anak bias menerapkannya di kehidupan sehari-hari."

Merujuk pada beberapa pernyataan diatas dapat diketahui bahwa kondisi profesionalisme guru akidah akhlak di MI Muhammadiyah Kartasura sudah cukup baik, akan tetapi masih perlu ditingkatkan lagi agar dapat menyesuaikan dengan tuntutan dan tantangan guru di zaman sekarang.

\section{Faktor Penghambat dan Pendukung yang dihadapi Kepala Kepala Sekolah}

\section{a. Faktor Penghambat yang dihadapi Kepala Sekolah}

Hambatan pertama, yang dihadapi kepala sekolah dalam meningkatkan kompetensi profesional guru akidah akhlak adalah masalah sarana prasarana. Sebagaimana hasil wawancara langsung 
dengan Bapak Adi selaku kepala sekolah MI Muhammadiyah Kartasura, sebagai berikut:

"Fasilitas di sekolah kami masih belum sepenuhnya lengkap seperti sekolah-sekolah lainnya, akan tapi kami terus berupaya untuk meningkatkan sarana dan prasarana disekolah kami agar dapat menunjang kegiatan pembelajaran dikelas maupun di luar kelas."

Begitu juga halnya yang diungkapkan oleh Ibu Ummi selaku guru akidah akhlak, beliau menuturkan bahwa:

"Untuk kendala yang menghambat dalam pembelajaran ada beberapa mas, misalkan salah satunya adalah dari sarana prasarana. Di MI Muhammadiyah Kartasura ini proyektornya masih terbatas, sehingga masihbeberapa kelas saja yang memakai proyektor. Jadi kalau saya inginmengajar dengan proyektor harus tukar kelas dulu mas dengankelas yang ada proyektornya."

Hambatan kedua, yang dihadapi kepala sekolah dalam meningkatkan kompetensi profesional guru akidah akhlak adalah dari segi peserta didik di MI Muhammadiyah Kartasura ini yang kurang mendapat perhatian dari orang tuanya, sehingga menyebabkan rendahnya minat siswa terhadap pelajaran. Sebagaimana hasil wawancara langsung dengan Bapak Adi selaku kepala sekolah sebagai berikut:

"Masih banyak siswa-siswi yang masih kurang mendapatkan perhatian dari orang tua mereka mas di sekolah ini masih. Sangat minim sekali mas dukungan dari orang tua mereka untuk memberikan motivasi kepada anaknya untuk belajar, sehingga yang terjadi anak tersebut menjadi malas belajar dan menyebabkan anak itu prestasinya tidak bisa meningkat. Juga dikarenakan sebagian besar dari wali murid disini bekerja sebagai buruh, karyawan dan latar belakang pendidikannya juga rendah."

Begitu juga halnya yang diungkapkan oleh Ibu Ummi selaku guru akidah akhlak, beliau menuturkan bahwa:

"Rata-rata siswa-siswi disini kurang mendapat perhatian dari orang tua mereka mas. Orang tua mereka terkesan masih kurang peduli terhadap pendidikan anaknya, Jadi membuat minat belajar mereka di sekolah menjadi berkurang. Hal inilah yang membuat saya sulit dalam memahamkan siswa terkait materi yang diajarkan." 
Dari sini kita tahu bahwa faktor yang kerap kali menghambat kepala sekolah dalam meningkatkan profesionalisme guru adalah dalam segi sarana dan prasarana sekolah yang kurang lengkap. Hal ini seharusnya dapat diatasi kepala sekolah agar kegiatan pembelajaran tidak terhambat hanya dengan fasilitas sekolah yang kurang lengkap. Selain itu faktor yang menghambat lainnya adalah faktor peserta didiknya yang kurang mendapat perhatian orang tuanya. Sehingga ketika di sekolah siswa tersebut susah mengikuti pelajaran dan akhirnya menghambat guru dalam meningkatkan prestasi peserta didiknya.

\section{b. Faktor Pendukung Kepala Sekolah}

Faktor yang mendukung peningkatan profesionalisme guru akidah akhlak yang pertama, adalah latar belakang dari guru itu sendiri. Selain memiliki latar belakang dengan kualifikasi S1, guru-guru di MI Muhammadiyah Kartasura ini terbilang memiliki latar belakang yang baik, seperti diantaranya ada yang berasal dari lulusan pondok pesantren, dan juga beberapa diantaranya ada yang menjaditokoh yang berperan penting dalam masyarakat di daerahnya. Hal ini dituturkan langsung oleh kepala sekolah yakni bapak Adi berikut:

"Kalau faktor pendukung sendiri, salah satunya adalah guruguru disini memiliki latar belakang yang bagus mas, baik akademik maupun non-akademik. Ada guru yang latar belakang agamanya bagus karena juga lulusan pondok pesantren, dan ada juga guru yang menjadi panutan atau tokoh masyarakat di kampungnya. Sedangkan guru akidah akhlak disini sendiri juga dulu lulusan pondok, jadi pengetahuan agamanya cukup bagus. Guru akidah akhlak juga terbantu dengan banyaknya guru disini yang juga punya latar belakang keagamaan yang bagus sehingga banyak membantu dalam kegiatan-kegiatan keagamaan di sekolah."

Sedangkan untuk faktor yang menunjang lainnya adalah terkait dengan kerjasama antar guru yang cukup bagus. Antara guru yang satu dengan yang lain sama-sama saling membantu jika ada guru yang mengalami kendala dan kesulitan baik dalam membuat adminstrasi atau perangkat pembelajaran maupun dalam kegiatan belajar mengajar. Hal tersebut seperti yang dituturkan oleh Ibu Dewi, selaku wakil kepala sekolah, beliau menuturkan bahwa :

"Guru-guru disini saling bantu satu sama lain mas, jadi kalau ada guru yang mengalami kesulitan dalam hal administrasi pembelajaran guru yang lain membantu untuk mengajari guru yang kesulitan itu tadi. Selain itu, guru-guru disini juga 
saling memberi motivasi dan masukan agar kita semua bisa saling intropeksi diri untuk menjadi lebih baik lagi."

Merujuk pada beberapa pernyataan diatas dapat kita ketahui bahwa adanya kerja sama antar sesama guru dapat membantu satu sama lain untuk menghadapi kesulitan-kesulitan maupun permasalahan dalam kegiatan belajar mengajar di sekolah.

\section{Kesimpulan}

Seorang guru agar dapat meningkatkan profesionalismenya dalam melaksanakan tugas sebagai seorang guru, dia harus memahami, menguasai, dan terampil dalam menggunakan sumber-sumber belajar baru. Dorongan dan motivasi perlu diberikan kepada guru untuk menemukan berbagai alternatif metode dan cara mengembangkan proses pembelajaran sesuai dengan perkembangan zaman. Maka sudah sepatutnya peran kepala sekolah sangat diperlukan dalam meningkatkan profesionalisme bagi semua guru, termasuk juga pada guru akidah akhlak.

Peran atau upaya yang ditempuh kepala sekolah dalam meningkatkan kompetensi profesional guru akidah akhlak antara lain adalah peran sebagai educator, manajer, administrator, supervisor, dan motivator. Dalam hal ini Kepala MI Muhammadiyah Kartasura telah menunjukkan fungsi dan perannya secara nyata dalam upaya meningkatkan profesionalisme guru akidah akhlak, seperti memberikan bimbingan kepada guru-guru dan siswa serta mengikutsertakan para guru dalam berbagai pelatihan, KKG, MGMP, workshop, dan sebagainya. Kepala MI Muhammadiyah Kartasura juga menjalankan perannya sebagai manajer dan administrator dengan menyusun berbagai program mulai dari program jangka pendek hingga program jangka panjang serta mengelola berbagai administrasi sekolah. Di samping itu, kepala MI ini juga senantiasa mengevaluasi kinerja guru-guru dalam kegiatan pembelajaran dan tidak lupa juga memberikan dorongan serta motivasi kepada guru-guru agar dapat meningkatkan kinerjanya.

Faktor penghambat kepala sekolah dalam meningkatkan profesionalisme guru akidah akhlak di MI Muhammadiyah Kartasura yang pertama adalah masalah dari segi sarana prasarana yang kurang menunjang untuk melaksanakan kegiatan pembelajaran. Selain itu dari segi peserta didik yang kurang mendapat perhatian dari orang tua sehingga ketika di sekolah peserta didik tersebut lambat dalam mengikuti pelajaran dan menghambat guru dalam meningkatkan prestasi peserta didiknya.

Sedangkan faktor pendukung kepala sekolah dalam meningkatkan profesionalisme guru akidah akhlak di MI Muhammadiyah Kartasura yang pertama adalah guru-guru yang memiliki latar belakang pendidikan yang baik seperti mayoritas adalah lulusan sarjana dan memiliki latar belakang pendidikan keagamaan yang baik. Selain itu adanya kerjasama yang baik antara guru dengan sesama guru, dan guru dengan kepala sekolah. Hal ini 
membantu guru tersebut dalam mencari solusi terhadap berbagai permasalahan yang dihadapi.

\section{Daftar Pustaka}

A.M, Sardiman. 2005. Interaksi Dan Motivasi Belajar Mengajar. Jakarta: Rajawali Pres

Abdul, Majid. 2012. Perencanaan Pembelajaran. Bandung: Rosda Karya

Achmad, Sanusi, 2009. Kepimpinan Sekarang Dan Masa Depan Dalam Membentuk Budaya Organsiasi Yang Efektif. Bandung. Prospect

Akbar, Sa'dun. 2013. Instrumen Perangkat Pembelajaran. Bandung: Rosdakarya.

Ali, Mohammad dan Mohammad Asrori. 2005. Psikologi Remaja Perkembangan Peserta Didik. Jakarta: Bumi Aksara

Anwar, Rosihon. 2010. Akhlak Tasawuf. Bandung: CV. Pustaka Setia

Arifin, H.M. 1998. Kelembagaan Agama Islam dan UT. Jakarta

Asti, Aslini Midar. 2017."Strategi Kepala Sekolah Dalam Peningkatan Kompetensi Guru Dan Kualitas Pembelajaran Pada Mata Pelajaran Pendidikan Agama Islam Di Smp Negeri 11 Kota Bengkulu". Tesis IAIN Bengkulu.

BA, Saebani, A Hamid. 2010. Ilmu Akhlak. Bandung: Pustaka Setia

Baharudin, \& Esa Nur Wahyuni. 2007. Teori Belajar dan Pembelajaran. Yogyakarta:Ar-Ruzz Media.

Benge, Eugene J., 1994, Pokok-pokok Manajemen Modern, Terj. Rochmulyati Hamzah, Jakarta: Pustaka Benama Pressindo.

Carter, 1989. Pengantar Kepemimpinan pendidikan, Surabaya : Usaha Nasional

Cece Wijaya dan Tabrani Rusyan, 200o. Kemampuan Dasar Guru Dalam Proses BelajarMengajar, Bandung: Remaja Rosdakarya 
Danim, Sudarwan, 2002. Inovasi Pendidikan Dalam Upaya Peningkatan Profesionalisme Tenaga Kependidikan. Bandung: CV. Pustaka Setia

Em Zul, Fajri dan Ratu Aprilia Senja, 2008. Kamus Lengkap Bahasa Indonesia. Semarang: Difa Publisher.

Hadari, Nawawi. 1998. Metode Penelitian Bidang Sosial. Yogyakarta:Gadjah Mada University Press.

Hamalik, Oemar. 2002. Pendidikan Guru Berdasarkan Pendekatan Kompetensi. Jakarta : Bumi Aksara.

Hamdani. 2011. Strategi Belajar Mengajar. Bandung : Pustaka Setia.

Hidayat, Junaidi. 2009. Ayo Memahami Akidah dan Akhlak 2 untuk MTs/SMP Islam Kelas VIII. Jakarta : Erlangga

Ishaq, Isjoni. 2008. Guru Sebagai Motivator Perubahan. Yogyakarta : Pustaka Pelajar

Koontz, Harold Cyril O'Donnel, 1980, Management, Edition VII, Tokyo: Mc Graw-Hill Kogakusha, Ltd

Kunandar, 2008. Guru Profesional Implementasi Kurikulum Tingkat Satuan Pendidikan (KTSP)dan Sukses dalam Sertifikasi Guru. Jakarta: PT. Raja Grafindo Persada

Lubis, Suwardi, 1987. Metodologi Penelitian Sosial, Medan: USU PRESS.

Makmum, Abin Syamsuddin. 2005, Psikologi Kependidikan Perangkat Sistem Pengajaran Modul. Bandung: Remadja Rosdakarya

Manulang, M., 2002, Dasar-Dasar Manajemen, Yogyakarta: Gajah Mada University Press.

Miles, Matthew B, and Huberman, A.Michael. 1992. Analisis data Kualitatif. Penerjemah: Rohidi. Jakarta; Universitas Indonesia.

Muchtar, Heri Jauhari, 20o8. Fiqih Pendidikan. Bandung: Remaja Rosdakarya

Mudlofir.A, 2012. Pendidik Profesional: Konsep, Strategi dan Aplikasinya Dalam Peningkatan Mutu Pendidikan di Indonesia, Jakarta: Rajawali Press

Muhaimin, 2004. Wacana Pengembangan Pendidikan Islam. Yogyakarta: Pustaka Pelajar, 
Mulyasa, E. 2005. Menjadi Guru Profesional. Bandung: PT. Remaja Rosda Karya Karya. . 2007. Standar Kompetensi dan Sertifikasi Guru. Bandung : Rosda . 2009. Menjadi Guru Profesional Menciptakan Pembelajaran Kreatif dan Menyenangkan. Bandung : Rosda Karya.

Natawidjaja, Rochman. 2002. Bimbingan Pendidikan dalam Sekolah Pembangunan. Semarang: IKIP Semarang

Nawawi, Hadari, 1999. Organisasi Sekolah dan Pengelolaan Kelas Sebagai Lembaga Pendidikan. Jakarta: CV. Haji Masagung

Nuraidah, 2013. Kompetensi Profesional Guru Untuk Meningkatkan Mutu Pembelajaran Di Madrasah Ibtidaiyah Negeri Sei Agul Medan, Tesis IAIN Sumatera Utara Medan

Nur Mufidah, Luk Luk, 2008. Supervisi Pendidikan. Jember: Center for Society Studies

Nurhadi, Syafruddin. 2002. Guru Dan Implementasi Kurikulum. Jakarta: Ciputat press

Nurichsan, 2016. "Peranan Kompetensi Guru Dalam Meningkatkan Prestasi Belajar Bahasa Arab Peserta Didik Pada Madrasah Tsanawiyah Makkaraeng Di Kabupaten Maros". Tesis Program Pasca Sarjana Universitas Islam Negeri Alauddin Makassar

Purwanto, Ngalim. 2006. Administrasi dan Supervisi Pendidikan, Bandung: PT. Remaja Rosdakarya

Prof. Pupuh Fathurrohman, M. Sobry Sutikno, M.Pd. 2007, Strategi Belajar Mengajar. Bandung: PT Refika Aditama.

Rosyid, Moh. 2007. Guru, Kudus: STAIN Kudus Press

Sagala, Syaiful, 200o. Administrasi Pendidkan Kontemporer, Bandung: CV. Al Fabeta

Satori, Djam'an dan Komariah, Aan, 2009. Metodologi Penelitian Kualitatif, Bandung: Alfabeta, Cet. I,

Soekidjo, Notoatmodjo, 1998. Pengembangan Sumber Daya Manusia. Jakarta: Rineka Cipta 
Siagian, S.P. 1992. Organisasi Kepemimpinan \& Perilaku Administrasi. Jakarta: Rineka Cipta. . 1980. Filsafat Administrasi, Jakarta: Mas Agung.

Silalahi, Ulbert. 1996. Pemahaman Praktis Asas-asas Manajemen, Bandung : Madar Maju.

Siregar, Evelin dan Hartini Nara. 2011. Teori Belajar dan Pembelajaran. Bogor: Ghalia Indonesia.

Subardi, Agus, 1997, Pengantar Manajemen, Yogyakarta: UUP AMP YPKN.

Sudrajat, Hari, 2004. Manajemen Peningkatan Mutu Berbasis Sekolah, Bandung: Cipta CekasGrafika

Sugiyono, 2005. Memahami Penelitian Kualitatif, Bandung: Alfabeta ,2008. Metode Penelitian Bisnis. Alfabeta : Bandung. 2009. Metode Penelitian Administrasi Dilangkapi dengan Metode $R \mathcal{E} D$. Cet. XVII; Bandung: Alfabeta,

Sulistyorini, 2009. Manajemen Pendidikan Islam, Yogyakarta: Teras

Surakhmad, Winarno. 1998. Pengantar Penelitian Ilmiah: Dasar, Metode, dan Teknik. Bandung: Tarsito

Suyono dan Hariyanto. 2011. Belajar dan Pembelajaran. Bandung : PT Remaja Rosdakarya.

Syaefudin U. S, 2009. Pengembangan Profesi Guru. CV. Alfabeta.

Syahidin. 2009. Menelusuri Metode Pendidikan dalam Al-Qur'an. Bandung: Alfabeta

Swasto, Bambang. 1996. Manajemen Sumber Daya Manusia. Malang: Fakultas Ilmu Administrasi Universitas Brawijaya

Tafsir, Ahmad. 2011. Ilmu Pendidkan Islam. Bandung: Remaja Rosda Karya.

Terry, G.R. dan L.W Rue, 1986, Azaz-Azaz Manajemen (terj.) Winardi, Bandung: Alumni Press.

Tim pengembang bahan Ajar LPPKS. 2013. Bahan pembelajaran Diklat calon Kepala Sekolah, Latihan Kepemimpinan. Indonesia: LPPKS 
Uno, Hamza B. 2009. Profesi Kependidikan problema, Solusi dan Reformasi Pendidikan di Indonesia. Jakarta : Bumi Aksara. . 2012. Model Pembelajaran Menciptakan Proses Belajar Mengajar yang Kreatif dan Efektif. Jakarta: PT Bumi Aksara.

Usman, M. Uzer, 1999. Menjadi Guru Profesional. Bandung: Remaja Rosda Karya

Werther, William B. \& Keith Davis. 1996. Human Resources And Personal Management. Edisi kelima. New York: McGraw-Hill.

Widjaya, A. W., 1987, Perencanaan Sebagai Fungsi Manajemen, Jakarta: Bina Aksara.

Wahjosumidjo, 2005. Kepemimpinan Kepala Sekolah Tinjauan Teoritik dan Permasalahannya. Jakarta: Raja Grafindo Persada 